\title{
COMPARATIVE PERFORMANCE OF TWO BREAD WHEAT (TRITICUM AESTIVUM L.) GENOTYPES UNDER SALINITY STRESS
}

\author{
YASSIN, M. ${ }^{1}$ - EL SABAGH, A..$^{2 *}$ MEKAWY, A. M. M. ${ }^{3}$ - ISLAM, M. S. ${ }^{4}-$ HoSSAIN, A. ${ }^{5}-$ \\ BARUTCUlAR, C. ${ }^{6}-$ AlHARBY, H. ${ }^{7}-$ BAMAGOOS, A. $^{7}-$ LiU, L. ${ }^{8}$ - UEDA, A. ${ }^{8}-$ SANEOKA, H. ${ }^{8}$ \\ ${ }^{I}$ Wheat Research Department, Field Crops Research Institute, Agricultural Research Centre \\ 9 Mourad, Oula, Giza, Egypt \\ ${ }^{2}$ Department of Agronomy, Faculty of Agriculture, Kafrelsheikh University \\ 33156 Kafrelsheikh, Egypt \\ ${ }^{3}$ Department of Botany and Microbiology, Faculty of Science, Minia University \\ El-Minia 61519, Egypt \\ ${ }^{4}$ Department of Agronomy, Hajee Mohammad Danesh Science and Technology University \\ Dinajpur-5200, Bangladesh \\ ${ }^{5}$ Bangladesh Wheat and Maize Research Institute, Dinajpur-5200, Bangladesh \\ ${ }^{6}$ Department of Field Crops, Faculty of Agriculture, Cukurova University, 01330 Adana, Turkey \\ ${ }^{7}$ Department of Biological Sciences, Faculty of Science, King Abdulaziz University \\ 21589 Jeddah, Saudi Arabia \\ ${ }^{8}$ Laboratory of Plant Nutritional Physiology, Graduate School of Biosphere Science \\ Hiroshima University, Hiroshima, Japan \\ *Corresponding author \\ e-mail: ayman.elsabagh@agr.kfs.edu.eg
}

(Received $18^{\text {th }}$ Dec 2018; accepted $19^{\text {th }}$ Feb 2019)

\begin{abstract}
The study was conducted at a greenhouse of the Graduate School of Biosphere Science in Hiroshima University, Japan under the ambient conditions to find out the effect of salinity stress on some physiological and biochemical characteristics of two bread wheat genotypes and also to elucidate the salt tolerance mechanism of these wheat genotypes. Two wheat genotypes namely 'Sakha 95' and 'Misr 2' were exposed to 50,100 and $150 \mathrm{mM} \mathrm{NaCl}$ levels of salinity. Results showed that both genotypes were varied significantly for all traits under all levels of salt stress. Among the genotypes, growth of the genotype 'Misr 2' was found much better than the 'Sakha 95', with the maintaining a higher dry biomass. The genotype 'Misr 2' also maintained a high concentrations of soluble-sugars, proline, and various antioxidant enzymes activity such as glutathione reductase (GR), peroxidase (POD) and catalase (CAT) compared with genotype 'Sakha 95'; whereas, maintained a lower levels of lipid peroxidation represented by the malondialdehyde (MDA) concentration. Indicating that genotype 'Misr 2' has ability to survive under salinity stress than the genotype 'Sakha 95'. Similarly, salinity stress also significantly changed in $\mathrm{Ca}^{++}$contents and $\mathrm{Na}^{+} / \mathrm{Ca}^{++}$ratio in both wheat genotypes. The relative reduction in $\mathrm{Ca}^{++}$concentration and $\mathrm{Na}^{+} / \mathrm{Ca}^{++}$ratio was found higher in the genotype 'Sakha 95' than in 'Misr 2' and lead to showing the signs injury. Thus, the genotype 'Misr 2' would be useful to develop a salinity tolerant wheat varieties in the future breeding program.
\end{abstract}

Keywords: antioxidant, salinity stress, wheat, physiological characteristics

Abbreviations: APX, ascorbate peroxidase; ARC, Agriculture Research Center; CAT, catalase; MDA, malondialdehyde; POD, peroxidase; $\mathrm{NaCl}$, sodium chloride; GR, glutathione reductase; SOD, superoxide dismutase; ROS, reactive oxygen species; TBA, thiobarbituric acid; RWC, relative water content; $\psi_{\pi}$, the osmotic potential 


\section{Introduction}

Bread wheat (Triticum aestivum L.) is the leading widely grown food cereal around the globe, due to it wider adaptability as well as quality of nutritive values than other cereals. Similarly, in terms of production and acreage it is also stands first. It is as a strategic crop which has a significant role on the national economy of the third world countries (Barutcular et al., 2017; Yadav et al., 2018; Yildirim et al., 2018). Whereas, it demand is increasing day by day to meet the food security of increasing population (Hossain et al., 2012; Abdelaal et al., 2018; Jahan et al., 2019). At the same time the productivity of wheat across the globe is influenced by several abiotic stresses (i.e., heat, drought and salinity); among them soil salinity is the most important one, particularly in arid and semi-arid regions (Pitman and Läuchli, 2002; Rengasamy, 2010; Sommer et al., 2015; Out et al., 2018).

Soil salinity has considered as the foremost environmental difficulties that negatively influences the growth and development of plants by altering the physicobiochemical process (Allakhverdiev et al., 2000). Approximately a 60\% crop productivity in the world is loss due to soil salinity stress (Xie et al., 2016). Study depicts that nearly $20 \%$ of the total cultivated land across the world is under salt stress (Oproi and Madosa, 2014). It is well-understood that under salt stress, plants uptake high concentrations of soluble salts that lead to limit the uptake of water through the roots system, due to higher osmotic stress. As a result, limited water in plant cells influences the turgor and also changes the membrane stability (Sairam et al., 2002), and absorbed the high concentration of ions in plant cells which compete with the uptake of essential nutrients lead to nutrient deficiency (Goudarzi and Pakniyat, 2008). The most predominant salt in saline soil such as $\mathrm{NaCl}$ increases the concentration of $\mathrm{Na}^{+}$and $\mathrm{Cl}^{-}$level in the soil, which inhibits the uptake of nutrients like $\mathrm{Ca}^{++}, \mathrm{Mg}^{++}$and $\mathrm{K}^{+}$by the plants and subsequently increases the uptake of $\mathrm{Na}^{+}$and $\mathrm{Cl}^{-}$in susceptible plants (Khan et al., 1999).

A group of antioxidants such as glutathione reductase (GR), peroxidase (POD) and catalase (CAT) are normally linked with the plant which tolerance to various stresses, including salinity stress (Munns and Tester, 2008). Plants which are capable to preserve a high levels of soluble-sugars, proline, and various antioxidant enzymes such as GR, POD and CAT to inhibit a lower levels of lipid peroxidation by representing a malondialdehyde (MDA) and efficient reactive oxygen species (ROS) concentration scavenger (Abogadallah, 2010; Gill and Tuteja, 2010); also can maintain a lower level of stress-induced injuries (Munns and Tester, 2008; Sharbatkhari et al., 2013). Sairam et al. (2002) revealed that the increasing level of SOD, GR and APX (ascorbate peroxidase) activity in wheat varieties under salinity stress showed the better level of tolerancey against salinity stress. They also found that antioxidants such as soluble sugars, proline, glycine betaine and abscisic acid contents were also increased of these tolerance wheat varieties under salinity stress. Other findings revealed that $\mathrm{Na}^{+}$and $\mathrm{K}^{+}$concentrations in the plants' cell, and their ratio, and dry biomass of salt-induced plants are also an appropriate indicator for the screening of wheat genotypes that are tolerant to salt stress (Goudarzi and Pakniyat, 2008). Sánchez-Rodríguez et al. (2010) reported that susceptible wheat genotypes showed a higher degree of lipid peroxidation represented by the MDA and ROS concentration than the tolerant genotypes. Therefore, a well thoughtful of wheat physiological responses under salinity stress may assistance to develop wheat varieties which will be suitable to grow under salt stress condition through improving growth 
and yield. In the context, the current study was undertaken to know the effects of salinity stress on some physiological and biochemical characteristics of wheat and also to elucidate the salt tolerance mechanism of wheat genotypes.

\section{Materials and Methods}

\section{Location}

The study was undertaken in a greenhouse of the Graduate School of Biosphere Science in Hiroshima University, Japan under the ambient conditions

\section{Plant growth and stress treatment}

To fulfil the objectives of the present study, two Egyptian wheat genotypes namely 'Sakha 95' and 'Misr 2' were selected based on their agronomic performance. These two genotypes were collected from the Agriculture Research Center (ARC) in Egypt. For surface sterilization, seeds of two wheat genotypes were immersion in a $50 \%$ sodium hypochlorite solution for 30 minutes, and then carefully washed with distilledwater before sowing. Subsequently seeds were then soaked in tap-water for 24 hours at $28^{\circ} \mathrm{C}$. Then germinated seeds were transferred to a $20 \mathrm{~L}$ half strength Hoagland solution. Ten days after germination, all seedlings were transferred to either Hoagland solution (as a control) or solution supplemented with $\mathrm{NaCl}$ (salinity treatment) for 12 days. Salt concentration such as 50, 100 and $150 \mathrm{mM}$ (according to treatments) was applied gradually in 2 days' intermissions to avoid osmotic shock to the plants. The nutrient solution was continuously aerated with pumps and renewed every 2 days. The $\mathrm{pH}$ was adjusted at 5.0-6.0 daily. All treatments were arranged with a complete randomized design and were replicated in three times.

\section{Growth measurements}

Ten plants in all treatments were collected and separated into three parts (roots, stems and leaves) after 12 days of treatment imposition. Two sets of samples were prepared: one for recording dry weights (DW) for each plant after oven drying at $70^{\circ} \mathrm{C}$ for 3 days, and the other set was kept at $-80^{\circ} \mathrm{C}$ for physiological analyses.

\section{Measurement of lipid peroxidation (malondialdehyde; MDA) concentrations}

The lipid peroxidation (such as MDA) concentration was determined through the reaction of thiobarbituric acid (TBA) (according to Fu and Hung, 2001), from frozensamples $\left(-80^{\circ} \mathrm{C}\right)$. The lipid peroxidation concentration (MDA) was estimated by using a coefficient of absorbance $(535 \mathrm{~nm})$ of $155 \mathrm{mM}^{-1} \mathrm{~cm}^{-1}$.

\section{Measurements of $\mathrm{Na}^{+}, \mathrm{K}^{+}$and $\mathrm{Ca}^{++}$concentrations}

Dry biomass of root, stem, and leaves was ground finely in a sample mill separately (Model: Labo, Miser LM-Plus; Osaka Chemical Co., LTD, Japan). The fine powder was then used to determine the $\mathrm{Na}^{+}$and $\mathrm{K}^{+}$concentrations. For this, the powder was then digested with sulfuric acid $\left(\mathrm{H}_{2} \mathrm{SO}_{4}\right)$ and hydrogen peroxide $\left(\mathrm{H}_{2} \mathrm{O}_{2}\right)$ at 2:1 (v/v). The $\mathrm{Na}^{+}$ and $\mathrm{K}^{+}$concentrations were measured using a flame photometer (Model: ANA 135; Tokyo Photoelectric, Tokyo, Japan). The $\mathrm{Ca}^{++}$concentration was also determined by 
using an inductively coupled argon plasma method (Model: ICAP-575, Nippon Jarrel Ash, Kyoto, Japan).

\section{Measurement of sugar concentrations}

The dried ground sample of leaves was boiled with $80 \%(\mathrm{v} / \mathrm{v})$ ethanol in a hot water $\left(80^{\circ} \mathrm{C}\right.$ about 20 minutes; min). The mixture was then centrifuged at $2000 \mathrm{rpm}$ for $5 \mathrm{~min}$; after that the supernatant was collected, and the precipitate was exposed to two more times of the same extraction process. The sugar concentration was determined in the ethanol-soluble extract by anthrone reagent method with a spectrophotometer (Model: U-2001, Hitachi, Japan), using glucose solution as standard (according to Yemm and Willis, 1954).

\section{Measurement of leaf water potential}

The osmotic potential $\left(\psi_{\pi}\right)$ of cell sap and osmotic potential $\left(\psi_{\pi(100)}\right)$ at full turgor were measured by using a Wescor 5500 vapor pressure osmometer (Model: Wescor Inc., Logan, UT. USA), and was estimated by adjusting according to Wilson et al. (1979).

\section{Measurement of proline}

The proline was determined spectrophotometrically following the ninhydrin method as described by Bates et al. (1973), using L-proline as a standard and then determined using spectrophotometer (Model: U-3310, Hitachi, Ltd. Tokyo, Japan). For determination of proline, the dried ground samples were transferred to vials subjected to methanol extraction, and stored in the dark place at $4^{\circ} \mathrm{C}$.

\section{Antioxidant enzyme activities}

Protein Assay kit (Model: Bio-Rad DC, California, USA) and bovine serum albumin as a standard were used to estimate the activity of CAT (EC 1.11.1.6), POD and GR (EC 1.6.4.2). An amount of $0.5 \mathrm{~g}$ fresh sample was extracted according to the following method as described by Takagi and Yamada (2013). An aliquot of $1 \mathrm{ml}$ of the CAT assay mixture was also used which was contained $50 \mathrm{mM}$ potassium phosphate buffer ( $\mathrm{pH} 7.0$ ), $10 \mathrm{mM} \mathrm{H}_{2} \mathrm{O}_{2}$, and enzyme extract (5\%). A decline in $\mathrm{H}_{2} \mathrm{O}_{2}$ was recorded at $240 \mathrm{~nm}$ to know the enzyme activity which is expressed as mmol $\mathrm{H}_{2} \mathrm{O}_{2}$ consumed per minute. $1 \mathrm{ml}$ assay mixture containing $100 \mathrm{mM}$ phosphate buffer (pH 7.5), $0.1 \mathrm{mM}$ EDTA, $0.02 \mathrm{mM}$ NADPH, $0.02 \mathrm{mM}$ GSSG and 10\% enzyme extract were used to know the GR activity. The concentration of oxidized NADPH was determined by using the extinction coefficient $\left(6.22 \mathrm{mM}^{-1} \mathrm{~cm}^{-1}\right)$ and 1-unit GR activity defined as $\mu$ mol NADPH oxidized $\min ^{-1}$. For the measurement of POD activity, $1 \mathrm{ml}$ reaction mixture contained $15 \mathrm{mM}$ guaiacol, $73 \mathrm{mM}$ phosphate buffer, $10 \mathrm{mM} \mathrm{H}_{2} \mathrm{O}_{2}$ and $2 \%$ enzyme extract. Increase in absorbance was monitored at $470 \mathrm{~nm}$ for $1 \mathrm{~min}$ and the enzyme activity calculated using the extinction coefficient $\left(26.6 \mathrm{mM}^{-1} \mathrm{~cm}^{-1}\right)$ for tetraguaiacol (Chance and Maehly, 1955). One-unit POD activity was defined as mmol tetraguaiacol formed per min.

\section{Statistical analysis}

Data were arranged and statically observed through one-way of analysis of variance (ANOVA) (Kao and Green, 2007). Treatments mean variation under different salinity treatments were observed by using Duncan's Multiple Range Test (DMRT) at the 0.05 level of significance (Duncan, 1955). 


\section{Results and Discussion}

\section{Plant growth}

Both wheat genotypes exposed to $150 \mathrm{mM} \mathrm{NaCl}$ salt concentration showed that the salt stress highly influenced the leaf, stem \& root dry weight (Fig. 1). As compared with control, leaf, stem, and root dry weight (DW) of both the genotypes were reduced significantly under salt stress treatments. While, DW reduction of genotype 'Misr 2' was found a minimum than 'Sakha 95'. Considering the visible signs injury, genotype 'Sakha 95' showed the maximum signs injury than genotype 'Misr 2' (Fig. 1). In the present study, plant biomass in both genotypes were decreased with the increase in the level of salinity, and it might be due to salinity stress altered the normal physiological and biochemical activities of the salinity exposed plants, which lead to decrease the DW. The assumption of the present study related to the adverse effect of salinity on plant biomass was also confirmed by Munns et al. (2006) and Rahman et al. (2017). Similarly, Dayiragije and Lutts (2006) also revealed that under salinity stress susceptible plants persist under-developed due to a decrease in cell division, elongation and also limit the synthesis of growth hormones (auxin) which lead to decrease the total biomass of the affected plant.

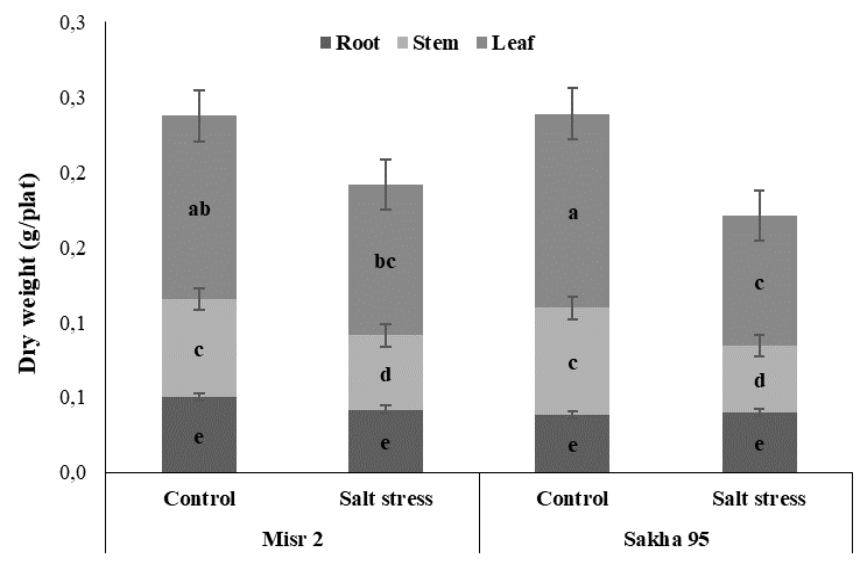

Figure 1. Effects of salinity stress on the dry weight of the leaf, stem, and root of two wheat genotypes recorded at 12 days after germination. The values of standard error $( \pm S E)$ in each bar were calculated for each treatment. The same letter indicates no significant difference $(p \leq 0.05)$ between each other

\section{$\mathrm{Na}^{+}, \mathrm{K}^{+}$concentrations and $\mathrm{Na}^{+} / \mathrm{K}^{+}$ratio}

Salinity treatments significantly influenced the $\mathrm{Na}^{+}, \mathrm{K}^{+}$concentration as well as the ratio of $\mathrm{K}^{+} / \mathrm{Na}^{+}$in all plant parts of both wheat genotypes. Under salt stress, accumulation of $\mathrm{Na}^{+}$increased in all of the organs of both genotypes; whereas the $\mathrm{Na}^{+}$ concentrations significantly differed between the two genotypes (Table 1). As compared with control plants, the $\mathrm{K}^{+}$concentration in all parts of the plants was decreased significantly in both genotypes. The lower $\mathrm{K}^{+}$concentration was found in the genotype 'Sakha 95' than the genotype 'Misr 2' under stress condition. However, under the control condition, the leaf $\mathrm{K}^{+}$concentration was significantly higher in genotype 'Sakha 95' than that of genotype 'Misr 2'. Our results revealed that the salt treatments remarkably reduced the leaf $\mathrm{K}^{+}$concentration in the genotype 'Sakha 95', whereas the 
reduction of $\mathrm{K}^{+}$concentration in the leaf of 'Misr 2' was minor as compared with control plants (Fig. 1).

Table 1. Effects of salinity on Na and $K$ concentration $\left(m g g^{-1} \mathrm{DW}\right)$ in the leaves, stems and roots of wheat. The values are the means $( \pm S . E)$ of three replicates. Means followed by the same letter within each line are not significantly different $(p<0.05)$

\begin{tabular}{c|c|c|c|c|c|c|c|c|c|c}
\hline \multirow{2}{*}{$\begin{array}{c}\text { Salt levels } \\
(\mathbf{m M} \text { NaCl })\end{array}$} & \multirow{2}{*}{$\begin{array}{c}\text { Wheat } \\
\text { genotypes }\end{array}$} & \multicolumn{3}{|c|}{$\mathbf{N a}^{+}\left(\mathbf{m g ~ g}^{-1} \mathbf{D W}\right)$} & \multicolumn{3}{c|}{$\mathbf{K}^{+}\left(\mathbf{m g ~ g}^{-1} \mathbf{D W}\right)$} & \multicolumn{3}{c}{$\mathbf{N a}^{+} / \mathbf{K}^{+}(\%)$} \\
\hline \multirow{2}{*}{$\mathbf{0}$} & Misr 2 & $5.9 \pm 0.04 \mathrm{c}$ & $6.1 \pm 0.04 \mathrm{c}$ & $7.7 \pm 0.03 \mathrm{c}$ & $69.6 \pm 1.3 \mathrm{a}$ & $90.4 \pm 1.3 \mathrm{~b}$ & $54.5 \pm 2.7 \mathrm{~b}$ & $8.5 \pm 0.2 \mathrm{ab}$ & $6.7 \pm 0.1 \mathrm{c}$ & $14.2 \pm 0.7 \mathrm{c}$ \\
& Sakha 95 & $5.8 \pm 0.01 \mathrm{c}$ & $6.3 \pm 0.10 \mathrm{c}$ & $6.9 \pm 0.15 \mathrm{c}$ & $68.5 \pm 0.7 \mathrm{ab}$ & $97.4 \pm 0.6 \mathrm{a}$ & $67.6 \pm 3.6 \mathrm{a}$ & $8.5 \pm 0.1 \mathrm{a}$ & $6.4 \pm 0.1 \mathrm{c}$ & $10.3 \pm 0.4 \mathrm{c}$ \\
\hline \multirow{2}{*}{$\mathbf{1 5 0}$} & Misr 2 & $29.1 \pm 0.52 \mathrm{~b}$ & $37.1 \pm 1.09 \mathrm{~b}$ & $30.2 \pm 0.58 \mathrm{~b}$ & $64.8 \pm 0.5 \mathrm{c}$ & $81.5 \pm 0.5 \mathrm{c}$ & $38.7 \pm 1.1 \mathrm{c}$ & $44.9 \pm 0.9 \mathrm{c}$ & $45.6 \pm 1.5 \mathrm{~b}$ & $78.1 \pm 1.1 \mathrm{~b}$ \\
& Sakha 95 & $34.7 \pm 1.03 \mathrm{a}$ & $41.5 \pm 1.18 \mathrm{a}$ & $36.1 \pm 1.72 \mathrm{a}$ & $66.4 \pm 0.6 \mathrm{bc} 80.2 \pm 1.8 \mathrm{c}$ & $42.2 \pm 1.2 \mathrm{c}$ & $52.3 \pm 1.6 \mathrm{bc} 51.9 \pm 2.5 \mathrm{a}$ & $85.45 \pm 3.1 \mathrm{a}$ \\
\hline
\end{tabular}

It is well-documented that lower $\mathrm{Na}^{+}$uptake and higher $\mathrm{K}^{+}$uptake are the key indicators of salinity tolerance in higher plants. In the present study, the $\mathrm{Na}^{+} / \mathrm{K}^{+}$ratio in the leaves, roots and stems of the genotype 'Misr 2' was significantly lower than the genotype 'Sakha 95'. When exposed to salinity stress, $\mathrm{K}^{+}$concentration in the leaves, roots and stems of both genotypes was decreased significantly, whereas, $\mathrm{Na}^{+}$ concentration was increased significantly, ultimately causing an increase in the ratio of $\mathrm{Na}^{+} / \mathrm{K}^{+}$, resulted in a serious deterioration of the ionic homeostasis in leaves, roots and stems of affected plants. Among the genotypes, $\mathrm{K}^{+}$concentration was not changed, but the $\mathrm{Na}^{+}$concentration and the $\mathrm{Na}^{+} / \mathrm{K}^{+}$ratio was changed and higher changed was found in genotype 'Sakha 95' than the genotype 'Misr 2' (Table 1). It is indicated that the genotype 'Sakha 95 ' is sensitive to salinity stress as a result of more accumulation of $\mathrm{Na}^{+}$concentration and the $\mathrm{Na}^{+} / \mathrm{K}^{+}$ratio, causing a serious visible injury signs in the leaves, roots and stems of affected plants, whereas genotype 'Misr 2' was found a tolerant genotype as the genotype did not show any signs injury under salinity stress. The results of the present study is agreement with the results of Benderradji et al. (2011), who noticed that salt sensitive wheat genotypes could exclude a lesser amount $\mathrm{Na}^{+}$effectively through the transpiration stream as a result of higher concentration of $\mathrm{Na}^{+}$entered in to the leaf blade, consequently a higher accumulation of $\mathrm{Na}^{+}$, and causing a cell injury. Similarly, Assaha et al. (2015), EL Sabagh et al. (2015) and Mekawy et al. $(2015,2018)$ revealed that the salt tolerant crops accumulated lower amount of $\mathrm{Na}^{+}$concentration in the shoots and leaf blades. Although, the leaf $\mathrm{K}^{+}$content has been suggested as a weak index of salt tolerance as compared to $\mathrm{Na}^{+}$content under field conditions, due to most of the susceptible genotypes do not change $\mathrm{K}^{+}$under salinity stress (El-Hendawi et al., 2009).

\section{$\mathrm{Ca}^{++}$concentrations and $\mathrm{Na}^{+} / \mathrm{Ca}^{++}$ratio}

Salinity stress significantly changed in $\mathrm{Ca}^{++}$concentration and $\mathrm{Na}^{+} / \mathrm{Ca}^{++}$ratio in the leaves, roots and stems of both wheat genotypes. While, a significant decline of $\mathrm{Ca}^{++}$ concentration was observed in the leaves, stems and roots of salt treated wheat plants, which leads to a significant increase of $\mathrm{Na}^{+}$, prompting an increment of the $\mathrm{Na}^{+} / \mathrm{Ca}^{++}$ ratio, resulting in a serious deterioration of the ionic homeostasis (Table 2). The relative reduction in $\mathrm{Ca}^{++}$concentration in the leaves, stems and roots of wheat plants was greater in the genotype 'Sakha 95 ' than in the 'Misr 2'. Similarly $\mathrm{Na}^{+} / \mathrm{Ca}^{++}$ratio in all 
plant parts of genotype 'Sakha 95' was found the higher than genotype 'Misr 2'. The results of the present study indicated that $\mathrm{Ca}^{++}$concentrations and $\mathrm{Na}^{+} / \mathrm{Ca}^{++}$ratio in the all plant parts was higher and lead to showing the signs injury under stress condition. The information of the present study is also confirmed by the earlier study as reported by Islam (2001) and Yusuf (2010), who revealed that accumulation of $\mathrm{Ca}^{++}$in plant parts inhibit to uptake other nutrients as well as altering the physiological and biochemical process. Similarly, Islam et al. (2011) found that higher accumulation of $\mathrm{Ca}^{++}$in the leaves under salt stress significantly inhibited the growth and development of foxtail-millet, whereas the inhibition of $\mathrm{Ca}^{++}$was found insignificant in porosomillet, indicated that proso-millet is tolerant to salinity stress than foxtail-millet.

Table 2. Effects of salinity on $\mathrm{Ca}^{++}$concentration $\left(\mathrm{mg} \mathrm{g}^{-1} \mathrm{DW}\right)$ in the leaves, stems and roots of both wheat genotypes. The values are the means ( \pm S.E) of three replicates. Means followed by the same letter within each line are not significantly different $(p<0.05)$

\begin{tabular}{c|c|c|c|c|c|c|c}
\hline \multirow{2}{*}{$\begin{array}{c}\text { Salt levels } \\
(\mathbf{m M ~ N a C l})\end{array}$} & \multirow{2}{*}{$\begin{array}{c}\text { Wheat } \\
\text { genotypes }\end{array}$} & \multicolumn{2}{|c|}{$\mathbf{C a}^{++}\left(\mathbf{m g ~ g}^{-\mathbf{1}} \mathbf{D W}\right)$} & \multicolumn{3}{c}{$\mathbf{N a}^{+} / \mathbf{C a}^{++}(\%)$} \\
\cline { 3 - 8 } & Leaf & Stem & Root & Leaf & Stem & Root \\
\hline \multirow{2}{*}{$\mathbf{0}$} & Misr 2 & $5.50 \pm 0.13 \mathrm{a}$ & $3.30 \pm 0.04 \mathrm{c}$ & $2.57 \pm 0.07 \mathrm{~d}$ & $107.02 \pm 1.82 \mathrm{c}$ & $183.42 \pm 2.67 \mathrm{c}$ & $298.68 \pm 6.56 \mathrm{c}$ \\
& Sakha 95 & $5.95 \pm 0.19 \mathrm{a}$ & $3.16 \pm 0.08 \mathrm{c}$ & $2.90 \pm 0.32 \mathrm{de}$ & $98.21 \pm 3.08 \mathrm{c}$ & $198.92 \pm 3.08 \mathrm{c}$ & $249.07 \pm 28.86 \mathrm{c}$ \\
\hline \multirow{2}{*}{$\mathbf{1 5 0}$} & Misr 2 & $3.76 \pm 0.17 \mathrm{~b}$ & $2.54 \pm 0.36 \mathrm{~d}$ & $1.74 \pm 0.06 \mathrm{e}$ & $776.88 \pm 26.19 \mathrm{~b}$ & $1,526.78 \pm 161.45 \mathrm{~b}$ & $1,736.13 \pm 34.78 \mathrm{~b}$ \\
& Sakha 95 & $3.51 \pm 0.13 \mathrm{~b}$ & $1.89 \pm 0.06 \mathrm{e}$ & $2.08 \pm 0.09 \mathrm{e}$ & $990.08 \pm 29.69 \mathrm{a}$ & $2,205.40 \pm 99.47 \mathrm{a}$ & $1,740.98 \pm 57.26 \mathrm{~b}$ \\
\hline
\end{tabular}

\section{Effects of salinity on proline concentration in the leaf of the wheat genotypes}

The increased levels of free proline in the leaf of both wheat genotypes under salinity stress conditions enhance the levels of antioxidant enzymes including proline activity which are natural responses of plants against stress. In the present study, the proline concentration in the leaves of both wheat genotypes was increased significantly under salt stress, whereas the accumulation level of proline varied remarkably between the genotypes. Among the genotypes, the genotype 'Sakha 95' showed a much higher level of proline accumulation than the genotype 'Misr 2' under salt treatment (Fig. 2). The results of the present study related to an accumulation of proline under salt stress also confirm by Szabados and Savouré (2010), who also noticed that the proline and total soluble carbohydrates synthesis influenced the growth and development of plant under stress conditions. To survive under stress, proline and soluble sugars could play a significant role in osmotic adjustment (Mafakheri et al., 2010). Similarly, Ueda et al. (2008) reported that proline accumulation under stress has been considered an adaptive character. They also found that higher proline synthesis during stress condition not only contribute to osmotic adjustment, but also improved the growth and development of the affected plants.

\section{Effects of salinity on osmotic potential $\left(\psi_{\pi}\right)$ of wheat genotypes under salinity stress}

The osmotic potential $\left(\psi_{\pi}\right)$ in both wheat genotypes was decreased significantly under saline condition (Fig. 3). Whereas, the genotype 'Sakha 95' exhibited a more negative potential than the cultivar 'Misr 2' under salinity treatment. Thus, the salinitytolerant genotype 'Misr 2' would display a higher osmotic adjustment than the sensitive genotype 'Sakha 95' under salinity stress conditions. The results of the present study indicated that water uptake of the plant under salinity stress was decreased due to changes in soil water potential. The information is also confirmed by Hussain et al. 
(2008), who reported that under different levels of salinity, the ionic flux in plant cell was increased that affected water potential of the plant's cell, ultimately lead to damage the plant cellular membranes. Similarly, Parida and Dus (2005) found that increasing level of osmotic potential under salt stress is due to high ion absorption and compartmentation in vacuole or the production of osmolytes is responsible for the osmotic adjustment in the cell of the sensitive plant. They also revealed that the increase of osmotic potential in salinity sensitive plants is due to the reduction of turgor pressure.

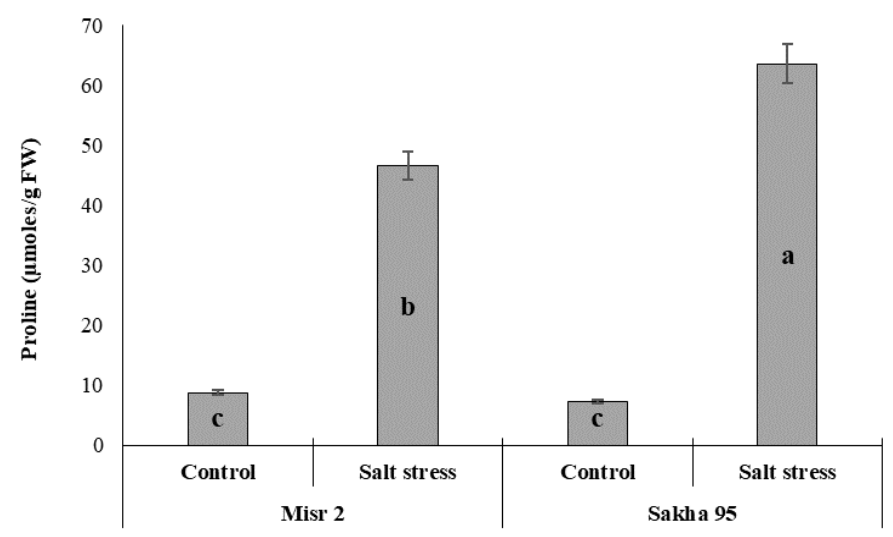

Figure 2. Effects of salinity on proline ratio in the leaf of the wheat genotypes 'Sakha 95' and 'Misr 2' after 12 days of salinity stress $(150 \mathrm{mM} \mathrm{NaCl})$. The values of standard error $( \pm S E)$ in each bar were calculated for each treatment for three replications. The same letter indicates no significant difference $(p \leq 0.05)$ between each other

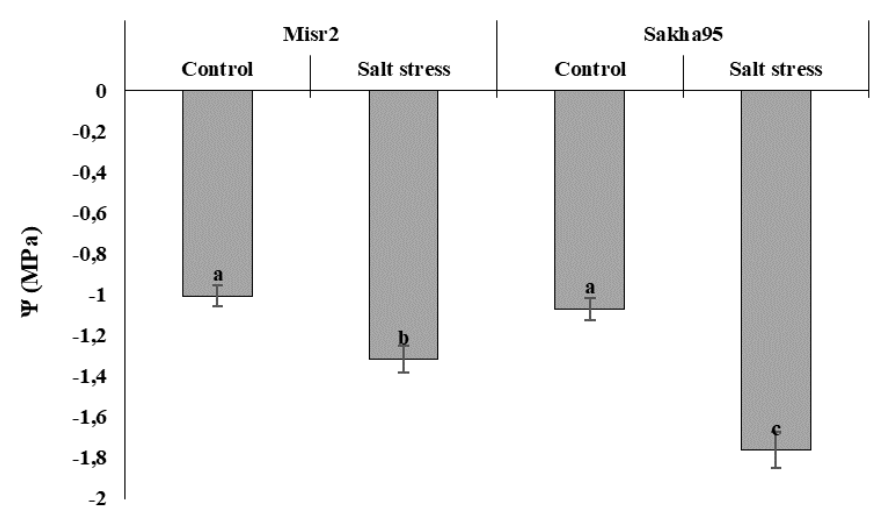

Figure 3. Effects of soil salinity on osmotic potential $(\psi \pi)$ in the leaf of the wheat genotypes 'Sakha 95' and 'Misr 2' after 12 days of salinity stress ( $150 \mathrm{mM} \mathrm{NaCl).} \mathrm{The} \mathrm{values} \mathrm{of} \mathrm{standard}$ error $( \pm S E)$ in each bar were calculated for each treatment for three replications. The same letter indicates no significant difference $(p \leq 0.05)$ between each other

\section{Effects of levels of salinity on Malondialdehyde concentration (MDA) of wheat genotypes}

The MDA is a product of lipid peroxidation (Meloni et al., 2003), which is accumulated in plant parts under stress condition. High degree of MDA concentration in plant parts has a correlation with oxidative damage of plant cell membranes (Assaha et al., 2015). Therefore, it has been used to identify the grade of oxidative damage under 
stressful conditions including salt stress also (Gill and Tetuja, 2010). In the present study, MDA concentrations was increased significantly in the leaves of the genotype 'Sakha 95' than in 'Misr 2' under salinity treatment (Fig. 4). Whereas, in the roots of salinity-induced plants, the increment of MDA concentrations were insignificant in both the genotypes; however, numerically increment of MDA in genotype 'Sakha 95' was much higher than that in the roots of genotype 'Misr 2'. The results of the present study related to the oxidative damage of plant cells' membranes due to the higher production of MDA also confirmed by earlier studies (Demiral and Türkan, 2005; Koca et al., 2007), who found that a higher concentration of MDA in plant cells indicated that the plant/crop is susceptible to salinity, whereas a lower MDA concentration indicates protection of plants against oxidative stress. They also revealed that with a small concentration of MDA in plant cells is usually corresponding to an increase in antioxidant enzyme activities in plant tissues that lead to help the plant to survive under stress condition.

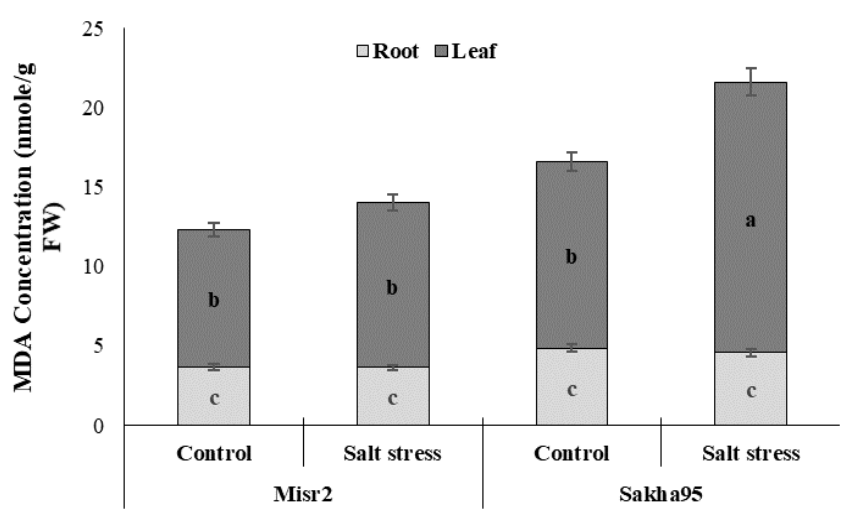

Figure 4. Effects of soil salinity on MDA concentration in leaf and root of the wheat genotypes 'Sakha 95' and 'Misr 2' after 12 days of salinity stress (150 $\mathrm{mM} \mathrm{NaCl).} \mathrm{The} \mathrm{values} \mathrm{of} \mathrm{standard}$ error $( \pm S E)$ in each bar were calculated for each treatment for three replications. The same letter indicates no significant difference $(p \leq 0.05)$ between each other

\section{Antioxidant enzymes activity under salinity stress in both genotypes}

Antioxidants such as CAT, APX, POD and GR are excellent scavengers of stressinduced oxidative damage (ROS). Therefore, an increase of antioxidant enzymes activities in plant cells indicate the stress tolerant ability of the plant and have a correlation with the reduction of oxidative damage (Mittler, 2002). In our present study, the activity of all antioxidant enzymes such as CAT and POD were markedly increased in the leaf of the genotype 'Misr2' under salt stress (Table 3). The activities of the antioxidant enzymes CAT and POD were significantly elevated by salt treatment in the leaves of the genotype 'Misr 2', while reduced in leaves of the genotype 'Sakha 95' by salinity treatment. However, glutathione reductase (GR) activity did not alter in the leaf of 'Misr 2', while reduced in 'Sakha 95' by salinity treatment. The activities of all the enzymes (i.e., CAT, POD, and GR) were significantly reduced by salinity treatment in the roots of 'Sakha 95' than 'Misr 2' (Table 3). In the roots of 'Misr 2, salt stress significantly induced the activity of GR and CAT as compared to controls (Table 3). The results of the present study related to antioxidant enzymes activity during stress condition were also described by Apel and Hirt (2004), who noticed that there is a correlation between CAT, POD, and GR activity and salt tolerance. Mittler (2002), Meloni et al. (2003), Tammam et 
al. (2008) and Elsawy et al. (2018) reported that antioxidant enzymes such as CAT, APX, POD and GR are excellent scavengers against the oxidative damage (ROS) under stress condition including salt stress; who also revealed that an increased level of antioxidants enzyme activities in plant cells indicate the plant has the ability to reduce oxidative damage. Furthermore, during water-deficit, the enhancement of antioxidant enzymes activity is a response to the photosynthetic machinery against damage caused by ROS (Pirasteh Anosheh et al., 2012; Abdelaal et al., 2017).

Table 3. Effects of salinity on POD (U/mg protein/min), CAT (U/mg protein/min) and GR (U/mg protein/min) in leaf and root of the wheat genotypes 'Sakha 95' and 'Misr 2' after 12 days of salinity stress $(150 \mathrm{mM} \mathrm{NaCl})$.The same letter indicates no significant difference $(p \leq 0.05)$ between each other. Means followed by the same letter within each line are not significantly different $(p<0.05)$

\begin{tabular}{c|c|c|c|c|c|c|c}
\hline \multirow{2}{*}{$\begin{array}{c}\text { Salt levels } \\
(\mathbf{m M ~ N a C l})\end{array}$} & \multirow{2}{*}{$\begin{array}{c}\text { Wheat } \\
\text { Variety }\end{array}$} & \multicolumn{2}{|c|}{ POD (U/mg protein/min) } & \multicolumn{2}{c|}{ CAT (U/mg protein/min) } & \multicolumn{2}{c}{ GR (U/mg protein/min) } \\
\cline { 3 - 8 } & Leaf & Root & Leaf & Root & Leaf & Root \\
\hline \multirow{2}{*}{$\mathbf{0}$} & Misr 2 & $0.067 \pm 0.003 \mathrm{ab}$ & $0.040 \pm 0.004 \mathrm{c}$ & $1.415 \pm 0.035 \mathrm{ab}$ & $0.652 \pm 0.073 \mathrm{~cd}$ & $2.50 \pm 0.13 \mathrm{e}$ & $3.39 \pm 0.20 \mathrm{c}$ \\
& Sakha 95 & $0.072 \pm 0.004 \mathrm{a}$ & $0.030 \pm 0.004 \mathrm{c}$ & $1.545 \pm 0.055 \mathrm{ab}$ & $0.525 \pm 0.032 \mathrm{de}$ & $3.02 \pm 0.19 \mathrm{~d}$ & $4.79 \pm 0.18 \mathrm{e}$ \\
\hline \multirow{2}{*}{$\mathbf{1 5 0}$} & Misr 2 & $0.077 \pm 0.004 \mathrm{a}$ & $0.015 \pm 0.001 \mathrm{~d}$ & $1.655 \pm 0.042 \mathrm{a}$ & $0.668 \pm 0.034 \mathrm{c}$ & $2.44 \pm 0.19 \mathrm{e}$ & $4.50 \pm 0.28 \mathrm{ab}$ \\
& Sakha 95 & $0.060 \pm 0.001 \mathrm{~b}$ & $0.018 \pm 0.002 \mathrm{~d}$ & $1.340 \pm 0.135 \mathrm{~b}$ & $0.503 \pm 0.019 \mathrm{e}$ & $2.21 \pm 0.12 \mathrm{e}$ & $3.96 \pm 0.11 \mathrm{bc}$ \\
\hline
\end{tabular}

\section{Conclusion}

From the results of the present study, it was found that both the genotypes were varied significantly for all traits under different levels of salinity, while the growth of the genotype 'Misr 2' was much better than that of 'Sakha 95', with the maintaining of higher dry biomass. The genotype 'Misr 2' also maintained a high concentrations of soluble-sugars and various antioxidant enzymes activity such as GR, POD and CAT compared with genotype 'Sakha 95'; whereas, maintained lower levels of lipid peroxidation represented by MDA concentration. Similarly, salinity stress also significantly changed in $\mathrm{Ca}^{++}$concentration and $\mathrm{Na}^{+} / \mathrm{Ca}^{++}$ratio in both wheat genotypes. Among the genotypes, the relative reduction in $\mathrm{Ca}^{++}$concentration and $\mathrm{Na}^{+} / \mathrm{Ca}^{++}$ratio was found the maximum in genotype 'Sakha 95' than in 'Misr 2' and lead to showing the signs injury. Thus, the genotype 'Misr 2' would be useful to develop a salinity tolerant wheat variety in the future breeding program. The above mentioned physiological and biochemical analyses may be useful as a model procedure for measuring the responses of other wheat genotypes to high-salinity in the field condition for development of salt tolerance genotypes in the future breeding program.

Conflict of interests. Authors declared no conflict of interests.

\section{REFERENCES}

[1] Abdelaal, Kh. A. A., Hafez, Y. M., EL Sabagh, A., Saneoka, H. (2017): Ameliorative effects of Abscisic acid and yeast on morpho-physiological and yield characteristics of maize plant (Zea mays L.) under water deficit conditions. - Fresen. Environ. Bull. 26(12): 7372-7383. 
[2] Abdelaal, Kh. A. A., Omara, I. R., Hafez, M. Y., Samar, M. E., EL Sabagh, A. (2018): Anatomical, Biochemical and Physiological Changes in Some Egyptian Wheat Cultivars Inoculated with Puccinia gramini f. sp. tritici $f$. sp. tritici f.sp. tritici. - Fresenius Environmental Bulletin 27(1): 296-305.

[3] Abogadallah, G. M. (2010): The antioxidative defense under salt stress. - Plant Signaling \& Behavior 5: 369-374.

[4] Allakhverdiev, S. I., Sakamoto, A., Nishiyama, Y., Inaba, M., Murata, N. (2000): Ionic and osmotic effects of $\mathrm{NaCl}$-induced inactivation of photosystem I and II in Synechococcus sp. - Journal of Plant Physiology 123: 1047-1056.

[5] Apel, K., Hirt, H. (2004): Reactive oxygen species: metabolism, oxidative stress, and signal transduction. - Annual Review of Plant Biology 55: 373-399.

[6] Assaha, D. V. M., Liu, L., Mekawy, A. M. M., Ueda, A., Nagaoka, T., Saneoka, H. (2015): Effect of salt stress on Na+ accumulation, antioxidant enzyme activities and activity of cell wall peroxidase of Huckleberry (Solanum scabrum) and eggplant (Solanum melongena). - International Journal of Agriculture and Biology 17: 1149-1156.

[7] Barutcular, C., EL Sabagh, A., Koç, M., Ratnasekera, D. (2017): Relationships between Grain Yield and Physiological Traits of Durum Wheat Varieties under Drought and High Temperature Stress in Mediterranean Conditions. - Fresenius Environmental Bulletin 26(6): 4282-4291.

[8] Bates, L. S., Waldren, R. P., Teare, I. D. (1973): Rapid determination of free proline for water-stress studies. - Plant and Soil 39: 205-207.

[9] Benderradji, L., Brini, F., Amar, S. B., Kellou, K., Azaza, J., Masmoudi, K., Bouzerzour, H., Hanin, M. (2011): Sodium transport in the seedlings of two bread wheat (Triticum aestivum L.) genotypes showing contrasting salt stress tolerance. - Australian Journal Crop Science 5: 233-241.

[10] Chance, B., Maehly, A. C. (1955): Assay of catalase and peroxidase. - Methods in enzymology 2: 764-775.

[11] Demiral, T., Türkan, I. (2005): Comparative Lipid Peroxidation, Antioxidant Defense Systems and Proline Content in Roots of Two Rice Cultivars Differing in Salt Tolerance. - Environmental and Experimental Botany 53: 247-257. http://dx.doi.org/10.1016/j.envexpbot.2004.03.017.

[12] Duncan, D. B. (1955): Multiple ranges and multiple F tests. - Biometrics 11: 1-42. doi: $10.2307 / 3001478$.

[13] El-Hendawi, S. E., Ruan, Y., Hu, Y., Schmidhalter, U. (2009): A comparison of screening criteria for salt tolerance in wheat under field and controlled environmental conditions. J. Agron. Crop Sci. 195: 356-367.

[14] EL Sabagh, A., Omar, A. E., Saneoka, H., Barutcular, C. (2015): Comparative physiological study of soybean (Glycine max L.) cultivars under salt stress. - YYU J. Agri. Sci. 25: 269e284.

[15] Elsawy, H. I., Mekawy, A. M. M., Elhity, M. A., Abdel-dayem, S. M., Abdelaziz, M. N., Assaha, D. V., Ueda, A., Saneoka, H. (2018): Differential responses of two Egyptian barley (Hordeum vulgare L.) cultivars to salt stress. - Plant Physiol. Biochem. 127: 425435.

[16] Gill, S. S., Tuteja, N. (2010): Reactive oxygen species and antioxidant machinery in a biotic stress tolerance in crop plants. - Plant Physiology and Biochemistry 48: 909-930.

[17] Goudarzi, M., Pakniyat, H., (2008): Evaluation of wheat cultivars under salinity stress based on some agronomic and physiological traits. - Journal of Agriculture and Social Science 4: 35-8.

[18] Hossain, A., Teixeira da Silva, J. A., Lozovskaya, M. V., Zvolinsky, V. P., Mukhortov, V. I. (2012): High temperature combined with drought affect rainfed spring wheat and barley in south-eastern Russia: Yield, relative performance and heat susceptibility index. - J. Plant Breeding Crop Science 4(11): 184-196. 
[19] Hussain, M., Malik, M. A., Farooq, M., Ashraf, M. Y., Cheema, M. A. (2008): Improving drought tolerance by exogenous application of glycinebetaine and salicylic acid in sunflower. - Journal of Agronomy and Crop Science 194: 193-199.

[20] Islam, M. S. (2001): Morpho-Physiology of blackgram and mungbean as influenced by salinity. - An M.S. thesis. Dept. of Agronomy. Bangabandhu Sheikh Mujibur Rahman Agricultural University, Salna, Gazipur, Bangladesh.

[21] Islam, M. S., Akhter, M. M., EL Sabagh, A., Liu, L. Y., Nguyen, N. T., Ueda, A., Masaoka, Y., Saneoka, H. (2011): Comparative studies on growth and physiological responses to saline and alkaline stresses of Foxtail millet (Setariaitalica L.) and Proso millet (Panicummiliaceum L.). - Australian Journal of Crop Science 5: 1269-1277.

[22] Jahan, M. A. H. S., Hossain, A., Jaime, A., Da Silva, T., EL Sabagh, A., Rashid, M. H., Barutçular, C. (2019): Effect of Naphthaleneacetic Acid on Root and Plant Growth and Yield of Ten Irrigated Wheat Genotypes. - Pakistan Journal of Botany 51(2): DOI: 10.30848/PJB2019-2(11).

[23] Kao, L. S., Green, C. E. (2007): Analysis of variance: is there a difference in means and what does it mean? - The Journal of Surgical Research 144: 158-70.

[24] Khan, M. A., Ungar, I. A., Showalter, A. M. (1999): The effect of salinity on growth, ion content, and osmotic relations in Halopyrum mucronatum (L.) Stapf. - Journal of Plant Nutrition 22: 191-204.

[25] Koca, H., Bor, M., Özdemir, F., Türkan, İ. (2007): The effect of salt stress on lipid peroxidation, antioxidative enzymes and proline content of sesame cultivars. Environmental and Experimental Botany 60: 344-351. DOI: 10.1016/j.envexpbot.2006.12.005.

[26] Mafakheri, M., Siosemardeh, A., Bahramnejad, B., Struik, P. C., Sohrabi, E. (2010): Effect of drought stress on yield, proline and chlorophyll contents in three chickpea cultivars. - Australian Journal Crop Science 4: 580-585.

[27] Mekawy, A. M. M., Abdelaziz, M. N., Ueda, A. (2018): Apigenin pretreatment enhances growth and salinity tolerance of rice seedlings. - Plant Physiology and Biochemistry 130: 94-104.

[28] Meloni, D., Oliva, M., Martinez, C., Cambraia, J. (2003): Photosynthesis and activity of superoxide dismutase, peroxidase and glutathione reductase in cotton under salt stress. Environment and Experimental Botany 49: 69-76.

[29] Mittler, R. (2002): Oxidative stress, antioxidants and stress tolerance. - Trends in Plant Science 7: 405-410. doi:10.1016/S1360-1385(02)02312-9.

[30] Munns, R., James, R. A., Lauchli, A. (2006): Approaches to increasing the salt tolerance of wheat and other cereals. - Journal of Experimental Botany 57: 1025-1043.

[31] Munns, R., Tester, M. (2008): Mechanisms of Salinity Tolerance. - Annual Review of Plant Biology 59: 651-681.

[32] Ndayiragije, A., Lutts, S. D. (2006): Do exogenous polyamines have an impact on the response of a salt sensitive rice cultivar to $\mathrm{NaCl}$ ? - J. Plant Physiol. 163: 506-16.

[33] Oproi, E., Madosa, M. (2014): Germination of Different Wheat Cultivars under Salinity Conditions. - Journal of Horticulture, Forestry and Biotechnology 18: 89-92.

[34] Out, H., Celiktas, V., Duzenli, S., Hossain, A., El Sabagh, A. (2018): Germination and Early Seedling Growth of Five Durum Wheat Cultivars (Triticum durum desf.) Is Affected by Different Levels of Salinity. - Fresenius Environmental Bulletin 27(11): 7746-7757.

[35] Parida, A. K., Das, A. B. (2005): Salt tolerance and salinity effects on plants: a review. Ecotoxicology and Environmental Safety 60: 324-349.

[36] Pirasteh Anosheh, H., Emam, Y., Ashraf, M., Foolad, M. R. (2012): Exogenous application of salicylic acid and chlormequat chloride alleviates negative effects of drought stress in wheat. - Advance Studies in Biology 11: 501-520.

[37] Pitman, M. G., Läuchli, A. (2002): Global impact of salinity and agricultural ecosystems. - In: Salinity: environment-plants-molecules (pp. 3-20). Springer, Dordrecht. 
[38] Rahman, M., Zahan, F., Sikdar, S., EL Sabagh, A., Barutçular, C., Islam, M. S., Ratnasekera, D. (2017): Evaluation of salt tolerance mungbean genotypes and mitigation of salt stress through potassium nitrate fertilization. - Fresen. Environ. Bull. 26: 72187226.

[39] Rengasamy, P. (2010): Soil processes affecting crop production in salt-affected soils. Functional Plant Biology 37(7): 613-620.

[40] Sairam, R. K., Rao, K. V., Srivastava, G. C. (2002): Differential response of wheat genotypes to long term salinity stress in relation to oxidative stress, antioxidant activity and osmolyte concentration. - Journal of Plant Science 163: 1037-1046.

[41] Sánchez-Rodríguez, E., Rubio-Wilhelmi, M. D. M., Cervilla, L. M., Blasco, B., Rios, J. J., Rosales, M. A., Romero, L., Ruiz, J. M. (2010): Genotypic differences in some physiological parameters symptomatic for oxidative stress under moderate drought intomato plants. - Plant Science 178: 30-40.

[42] Sharbatkhari, M., Galeshi, S., Shobbar, Z., Nakhoda, B., Shahbazi, M. (2013): Assessment of agro-physiological traits for salt tolerance in drought-tolerant wheat genotypes. - International Journal of Plant Production 7: 437-454.

[43] Sommer, R., Glazirina, M., Yuldashev, T., Otarov, A., Ibraeva, M., Martynova, L., Bekenov, M., Kholov, B., Ibragimov, N., Kobilov, R., Karaev, S. (2013): Impact of climate change on wheat productivity in Central Asia. - Agriculture, ecosystems \& environment 178: 78-99.

[44] Szabados, L., Savouré, A. (2010): Proline: a multifunctional amino acid. - Trends Plant Science 15: 89-97.

[45] Takagi, H., Yamada, S. (2013): Roles of enzymes in anti-oxidative response system on three species of chenopodiaceous halophytes under NaCl-stress condition. - Soil Science and Plant Nutrition 59: 603-611.

[46] Tammam, A., Abou Alhamd, M. F., Hemeda, M. (2008): Study of salt tolerance in wheat (Triticum aestium L.) cultivar Banysoif 1. - Australian Journal Crop Science 1: 115-125.

[47] Ueda, A., Shi, W., Shimada, T., Miyake, H., Takabe, T. (2008): Altered expression of barley proline transporter causes different growth responses in Arabidopsis. - Planta 227: 277-286.

[48] Wilson, J. R., Fisher, J., Schulze, E. D., Dolby, G. R., Ludlow, M. M. (1979): Comparison between pressure-volume and dewpoint-hygrometry techniques for determining the water relations characteristics of grass and legume leaves. - Oecologia 41: 77-88.

[49] Xie, J., Dai, Y., Mu, H., De, Y., Chen, H., Wu, Z., Ren, W. (2016): Physiologicaland Biochemical Responses to NACl Salinity Stress in Three Roegneria (Poaceae) Species. Pakistan Journal of Botany 48: 2215-2222.

[50] Yadav, S. S., Redden, R. J., Hatfield, J. L., Ebert, A. W., Hunter, D. (2018): Food Security and Climate Change. - John Wiley \& Sons, Dec 14, 2018 - Technology \& Engineering - 568 pages.

[51] Yemm, E. W., Willis, A. J. (1954): The estimation of carbohydrates in plant extracts by anthrone. - Biochemical Journal 57: 504-508.

[52] Yıldırım, M., Barutçular, C., Hossain, A., Koç, M., Dizlek, H., Akinci, C., Toptaş, I., Basdemir, F., Islam, M. S., EL Sabagh, A. (2018): Assessment of The Grain Quality of Wheat Genotypes Grown Under Multiple Environments Using GGE Biplot Analysis. Fresenius Environmental Bulletin 27(7): 4830-4837.

[53] Yusuf, M. A., Kumar, D., Rajwanshi, R., Strasser, R. J., Tsimilli-Michael, M., Govindjee, Sarin, N. B. (2010): Overexpression of c-tocopherol methyl transferase gene in transgenic Brassica juncea plants alleviates abiotic stress: physiological and chlorophyll a fluorescence measurements. - Biochim. Biophys. Acta 1797(8): 1428-1438. 